\title{
The Meaning and Syntax of ta'̌̆rōg
}

\author{
Jonathan Nathan | ORCID: 0000-0002-6417-5729 \\ Faculty of History, University of Cambridge \\ Cambridge, United Kingdom \\ jsn32@cam.ac.uk
}

Published online: 26 April 2021

\begin{abstract}
The word ta ărōg, which appears three times in the Hebrew Bible, has been traditionally interpreted as a third-person feminine form. This article proposes that it instead be treated as a second-person masculine form, and that the two verses in which it appears be re-analysed accordingly.
\end{abstract}

\section{Keywords}

Biblical syntax - Psalm 42 - Joel - lexicology - sicut cervus

According to BDB and HALAT, the verb ערג is attested three times in classical Hebrew: once at Joel 1:20 and twice at Ps 42:2.

(David Stec, author of the volume ס-פ of the DCH, posits a fourth occurrence at Job 24:10. It is there attested, he says, in the present participle ערִִגים הִּלְכו, which is to be translated "they go about longing." He notes, however,

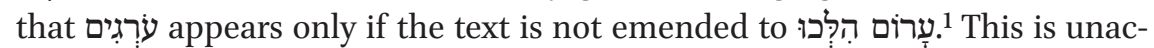
countable, for עָרוֹם הִּלְכו is already the Masoretic reading. The basis of Stec's statement is an article from 1974, whose author Arie de Wilde emended עָרוֹ

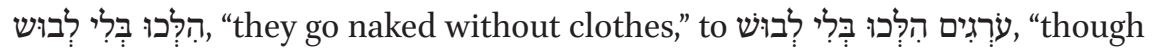
they weave, they go without clothes." with ארג, "to weave." David Clines, the general editor of the DCH, later cited de

1 Stec, $D C H 6$.

2 De Wilde, "Vervreemding." 
Wilde's article in his commentary on Job but silently corrected it, making the emended verse read "longing, they go without clothes." ${ }^{3}$ Stec then reproduced Clines' paraphrase in his entry for the DCH on ערג, but apparently mistook the emendation for the Masoretic text. The supposed fourth attestation of ערג is thus a garbled paraphrase of a charitable reworking of a garbled conjecture. It can be safely disregarded.)

In all three genuine attestations, the word takes the singular imperfect form תְִּׁרוֹג (spelt defectively in the latter verse). Here it is in Joel 1:20:

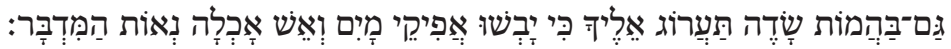

And here in Ps 42:2:

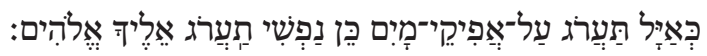

The word presents two problems which have vexed commentators for centuries. The first is lexical: the meaning of the verb ערג is unestablished. Some evidence for its sense comes from the context of its attestations. Joel 1:20 is

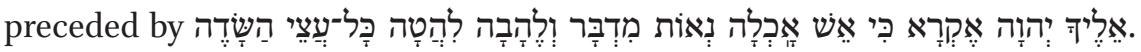
The verse itself is then introduced by

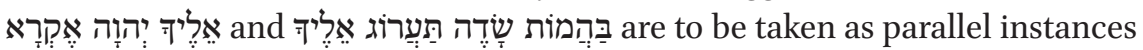

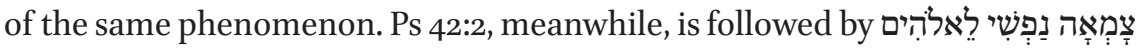

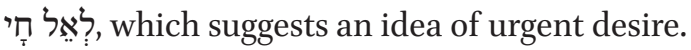

The earliest attested translations of תערוג seem to be guesses informed by these contexts. Joel 1:20 was rendered in the LXx like this:

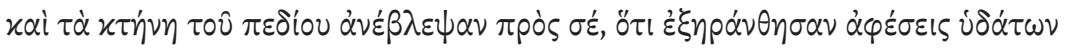

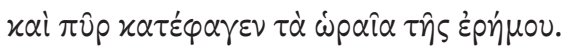

And Ps 42:2 like this:

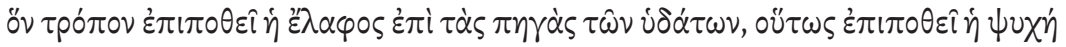

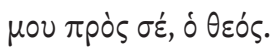

Similarly, the tenth-century grammarian Dunash ben Labrat glossed ערג contextually as "to cry out," making it a specialized synonym of קרא.

Aquila, for his part, used etymology rather than context to derive the mean-

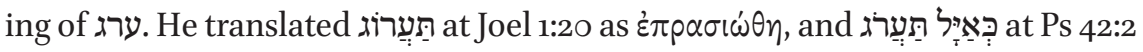

3 Clines, Job 21-37, 585 n. 10 . 
as $\dot{\omega} \varsigma \alpha \dot{\nu} \lambda \dot{\omega} \nu \pi \varepsilon \pi \rho \alpha \sigma \alpha \sigma \mu \varepsilon^{\prime} v o{ }^{4}{ }^{4}$ The basis of these translations was the resem-

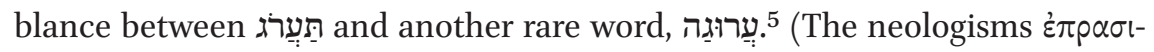
$\omega^{\prime} \theta \eta$ and $\pi \varepsilon \pi \rho \alpha \sigma \alpha \alpha \sigma \mu \varepsilon v \varepsilon^{\prime} \varsigma$ are derivatives of $\pi \rho \alpha \sigma \alpha^{\alpha}$, "planting bed," which Aquila had used to translate עִ עַרוּגַ wherever it appeared.) Later, Jerome-and thus the whole Latin tradition in the case of Joel 1:20-followed Aquila for the translation of these verses. ${ }^{6}$ Probably the word was just as mysterious to all of these pre-modern translators as it is to us.

Scholars since the mid-seventeenth century have tried to establish the meaning of ערג from Semitic cognates. In 1648, Louis de Dieu observed that $0<7$ in Ethiopic and عرج in Arabic both mean "to go up," and that Ps 42:2 could therefore be translated "sicut cerva ascendit ad decursus aquarum, sic anima mea ascendit ad te."7 In 1967 Edward Ullendorff, believing that he was making an innovative application of his learning in Ge'ez, unwittingly recapitulated de Dieu's conjecture. ${ }^{8}$

Two decades after it appeared, Samuel Bochart threw out de Dieu's translation on the grounds that a beast goes down, not up, to water. ${ }^{9}$ In its place he cautiously endorsed the opinion of Dunash that תַַּּרוֹג referred to a deer's cries, with the reservation that it could not refer only to deer, since at Joel 1:2o it takes all of the beasts of the field for its subject. Bochart also cited the myth of the huntress Argê, turned into a deer by the sun-god, and mused that her name was derivable from ערג

In 1669, Johannes Coccejus speculated that ערג was a derivative or a relative of ערך, with the meaning "to set out [a complaint]," as at Ps 5:4. Hence Ps 42:2 was presumably to be read "as a deer complains for the riverbeds...," and Joel 1:20 "as the beasts of the field complain ..."11

In the same year, Edmund Castell provided a list of cognates to ערג from Ge'ez and Arabic. From then on, any scholar could review the variety of meanings associated with both عرج 047 and Castell himself did not con-

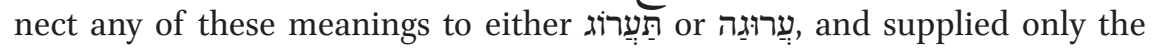

4 Field, Hexaplorum.

$5 \quad$ It appears at Ezek 17:7, 10; Cant 5:13; 6:2.

$6 \quad$ Psalm 42:2, in the Versio Hebraica: Sicut areola prceparata ad inrigationes aquarum, sic anima mea prceparata est ad te, Deus. Joel 1:20: Sed et bestice agri quasi area sitiens imbrem suspexerunt ad te. For the latter verse, Jerome was almost certainly influenced by a clause

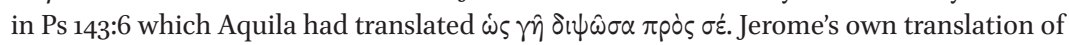
that verse, following Aquila, was anima mea quasi terra sitiens ad te.

7 De Dieu, Animadversiones, 330-331.

8 Ullendorff, Ethiopia and the Bible, 129.

9 Bochart, Hierozoicon, 884.

10 Bochart, Hierozoicon, $883^{-884}$.

11 Coccejus, Lexicon, 644. 
traditional glosses desideravit; glocitavit for the former and areola for the latter. ${ }^{12}$ A century later, however, Johann David Michaelis mined the cognates in Castell's entry to formulate a new hypothesis. In the first place, he endorsed de Dieu's theory that ערג means "ascendit." Then he posited that עַרוּגָ was indeed related to ערג, but that it must mean something raised, like a trellis, rather than a planting-bed. To prop up this conclusion he cited the Qur'anic word which Castell had recorded as meaning "ladder." ${ }^{13}$

Such was early-modern learning on the root ערג. Wilhelm Gesenius' muchcited dictionary entries were no more than résumés of this scholarship. He endorsed de Dieu's opinion and glossed ערג as "aufsteigen," but posited that

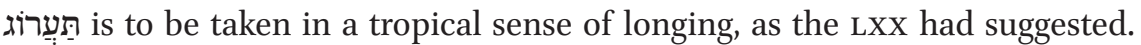
As for עִרגוּגה, he deprecated Aquila's translation "planting-bed" and cited Michaelis's conjecture with approval. ${ }^{14}$

Joshua Blau, departing from the tradition that Gesenius had transmitted, insisted on "to incline" as the basic meaning of ערג. He observed that the Arabic G-stem verb عَعَجَ, "to ascend," is only attested in the Qur’an in the very specialized sense of entering heaven. (The noun مَعَعَ is likewise used only in connection with heaven). ${ }^{16}$ The word in the sense of ascent was therefore likely borrowed; likely from Ethiopic, in which the ordinary meaning of $0<7$ is indeed "to go up." Consequently, عَعَ cannot be relied on as a straightfor-

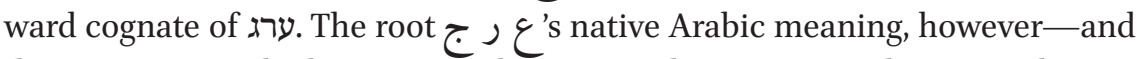
the meaning in which it is properly compared to ערג-is rather "to incline," a

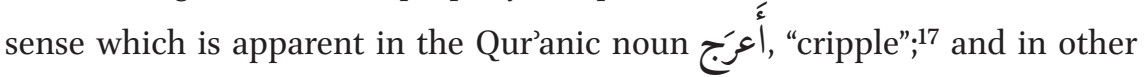
early Arabic sources in the collateral G-stem verb عَعَجَ "to limp; to incline,"18 in D-stem عَعَِّ "to turn, to lame," and in numerous other derivations of the root (most of which can incidentally be found in Castell's Lexicon). Blau contended from this evidence that Biblical ערג is best understood as a verb meaning "to incline." The Lxx's translations, moreover, were approximately correct all along, for "to long" is a plausible tropical extension of the verb's intransitive sense. Like Gesenius before him, Blau was perhaps motivated in the last stage

\footnotetext{
12 Castell, Lexicon heptaglotton.

13 Michaelis, Supplementa, 1968-1969.

14 Gesenius, Handwörterbuch, 892-894.

15 Blau, "לבירורץ."

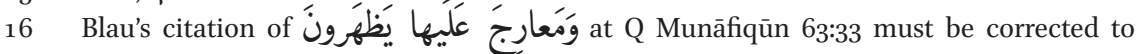
Q Zukhruf 43:33.

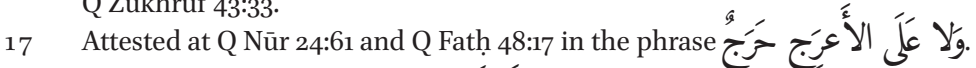

18 (Blau cited the phrase عَرجَت الشمس , "the sun went down," to which one might compare Lat. sol inclinat.)
} 
of his argument by a wish to save the appearance of the traditional translations. Below, by contrast, I will argue that there is no objection at all to treating תַתְׁרוֹג as a transitive verb, or even to interpreting it literally.

Putting the lexical problem aside for now, our second puzzle is grammatical.

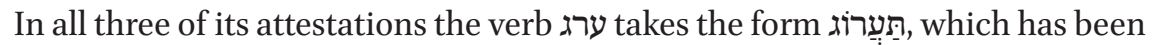
universally interpreted since the LXX as a 3 fs imperfect form. So understood, it does not agree with two of its three apparent subjects: plural anּ anה and masculine אָ.

In his commentary on Joel 1:20, Abraham ibn Ezra wrote that singular

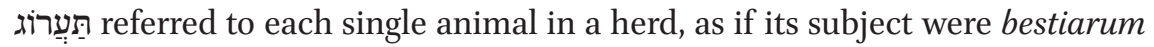
quceque. He cited בָּנוֹת צְעָדָה at Gen 49:22 as an example of the same phenom-

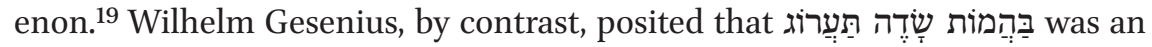
instance of a plural subject's taking a singular feminine predicate, just as nonhuman plurals do in Arabic. ${ }^{20}$ As for Ps 42:2, ibn Ezra noted that nouns which usually refer to male animals can sometimes denote females too, like עֶַ

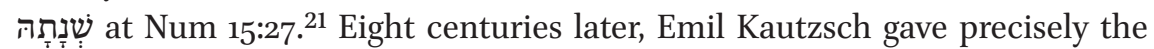
same explanation. ${ }^{22}$ All of these are serviceable ad-hoc exculpations of their respective verses, but none of them accounts on its own for both problematic

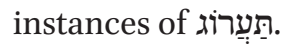

Twentieth-century editors of the Masoretic text saw another way out, offering emendations rather than grammatical explanations. Frants Buhl proposed

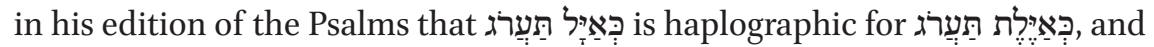
thus that the animal in question is a doe after all. ${ }^{23}$ All of his successors have followed him, down to Hans Bardtke in the B Hs. Thomas Cheyne, by contrast, suggested that תערג in Ps 42:2 had been metathesized from תגער, "cries out."24

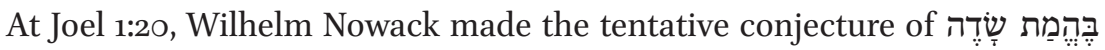

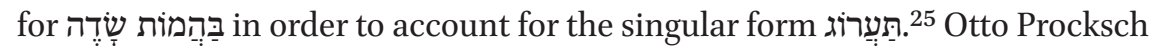
retained this emendation for the $\mathrm{BH}_{3}$, and even deleted Nowack's fortasse. Certainty, however, was no protection from posterity. Karl Elliger, editor for the BHS, recorded the conjecture, but deprecated it in favour of his own emenda-

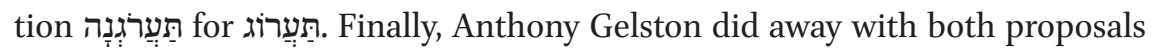
in the BHQ. ${ }^{26}$ It is just as well that he did so, for there is nothing to recommend Nowack or Elliger's emendations apart from the comfort of the lectio facilior.

\footnotetext{
גם בהמות תערג: כל אחת ואחת כדרך בנות צעד 19.

20 Gesenius, Hebräisches Elementarbuch, §143.3.

21 ואיל: על לשון נקבה כמו עז בת שנתה.

22 Kautzsch, Hebräische Grammatik, §122.2 n. 1.

23 Kittel, Biblia Hebraica.

24 Cheyne, "Occurrences of גער."

25 Kittel, Biblia Hebraica.

26 Gelston, Twelve Minor Prophets.
} 
Indeed, all these grammatical explanations and textual emendations are embarrassed attempts to evacuate the scandal of a rare verb that appears in only one form. It is that form, תְַּּרוֹ, which we must account for: parsimony warns against dodging the problem with piecemeal explanations.

I propose the following solution: ערג is to be treated in the first place as a

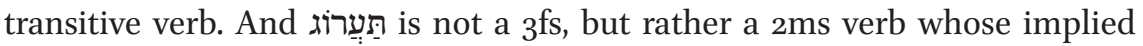

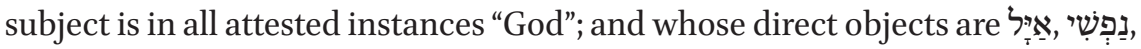

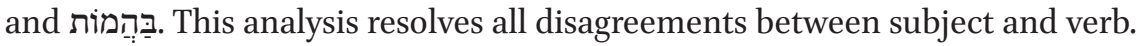
It also lets the Masoretic text stand without modification.

The sense of ערג need not be fixed here. But if we borrow Joshua Blau's hypothesis that ערג means "to bend" (without endorsing his further conclusions) we can read the verses like this:

Joel 1:20:

Quin et bestias agri ad te torques, nam alvei aquce exsiccati sunt, et ignis consumpsit prata deserti.

Thou also turnest the beasts of the field unto thee, for the rills of water are dried up, and fire hath consumed the meadows of the wilderness.

Ps 42:2:

Sicut cervum ad alveos aque, ita animam meam ad te torques, $O$ Elohim. As thou turnest a deer unto rills of water, so turnest thou my soul unto thee, O God.

This would be nothing unusual: נַפְּשִׁי is very often construed with verbs of spatial manipulation. ${ }^{27}$

Alternatively, we might attribute to ערג the same tropical sense as חול and torqueo, viz. "to torture":

Joel 1:20:

Quin et bestias agri de te angis, nam alvei aquae exsiccati sunt, etc.

Thou also puttest the beasts of the field in anguish for thee, etc.

Ps 42:2:

Sicut cervum de alveis aquee, ita animam meam de te angis, O Elohim.

As thou puttest a deer in anguish for rills of water, so puttest thou my soul in anguish for thee, $\mathrm{O}$ God. ${ }^{28}$

27 Cf. Pss. 25:1; 30:3; 37:17; 54:4; 142:7.

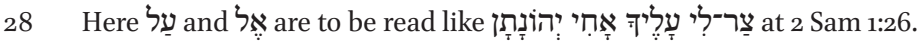




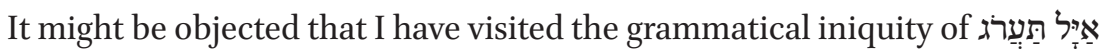

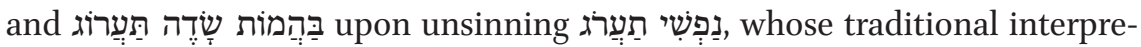
tation poses no problem of agreement. It is true that the SV interpretation anima mea desiderat is prima facie plausible. But it is no violent innovation

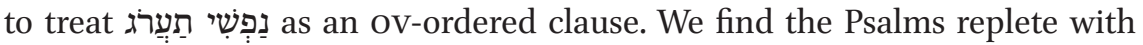
such constructions, even if we restrict our selection to the form נַפְשִׁי Consider,

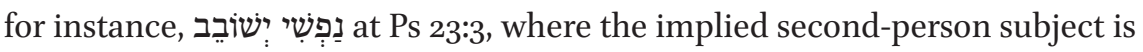
God, and where the predicate is placed after the object. Or else Ps 143:3, נַפְּשׁׁי

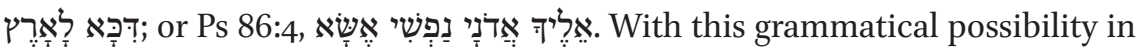
mind, indulge a thought experiment. Consider Ps 16:10: but imagine that עre were an otherwise-unattested root of unknown meaning.

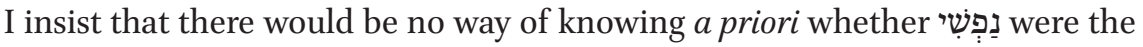

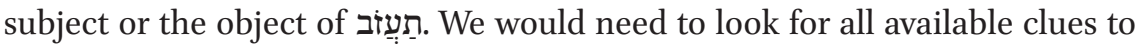
determine the answer and confess ignorance if none were available. In the case

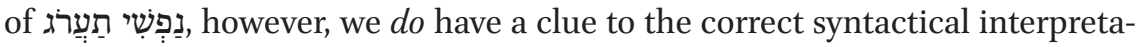

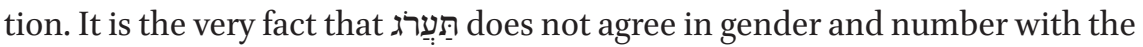
two nouns besides נָּפְשִ that are traditionally purported to be its subjects, and that it is much more comfortably treated in those cases as a transitive verb that takes those nouns as objects.

Besides their advantages in agreement, my readings also eliminate a serious syntactical difficulty, which is that עַ and would be awkward prepositional complements for a verb meaning "to long." Consider Ps 63:1:

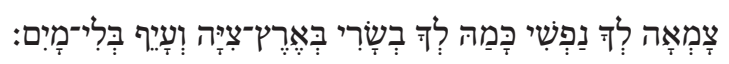

And Ps 42:3:

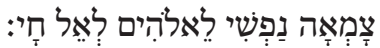

The traditional view is that Joel 1:20 and Ps 42:2 are parallel cases in syntax as well as meaning to these two passages. Observe, however, that

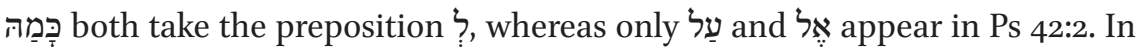
fact, Hebrew verbs of hungering, thirsting, and longing almost always take the

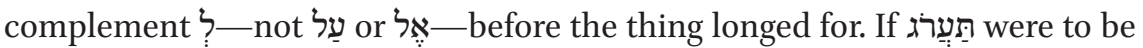

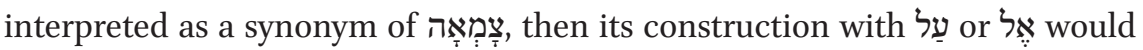

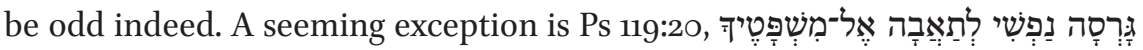

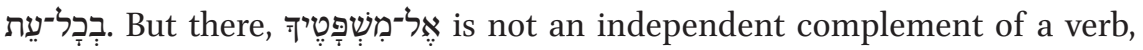
but is rather set within a prepositional phrase that complements the object-

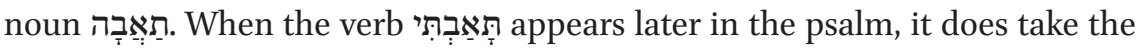
complement ?ִ after all. 
The LXX, the Rabbis, and our dictionaries tell us that תִ תִ is an intransitive ${ }_{3} \mathrm{f}$ form. But tradition is no substitute for the evidence, which urges us to draw another conclusion.

\section{Bibliography}

Blau, Joshua. "לבירורן של מקבילות עבריות לאוזר המלים המקראי מוגים לשון: מוגשים לזאב בן־חיים בהגיעו לשיבה ל- Edited by Moshe Bar-Asher, David Tene, and Gad Ben-Ami Tzarfati. Jerusalem: Magnes, 1983.

Bochart, Samuel. Hierozoicon, sive bipertitum opus de animalibus sacrce scripturce. Vol. 1. London: Thomas Roycroft, 1663.

Castell, Edmund. Lexicon heptaglotton. London: Thomas Roycroft, 1669.

Cheyne, Thomas Kelly. "Occurrences of גער in the Old Testament." ZAW 31 (1911): 315.

Clines, David J. A. Job 21-37. WBC 18A. Nashville, TN: Thomas Nelson Publishers, 2006.

Coccejus, Johannes. Lexicon et commentarius sermonis Hebraici et Chaldaici Veteris Testamenti. Amsterdam: Johannes à Someren, 1669 .

de Dieu, Louis. Animadversiones in Veteris Testamenti libros omnes. Leiden: Bonaventure \& Abraham Elzevir, 1648.

Field, Frederick, ed. Origenis Hexaplorum quce supersunt sive Veterum Interpretum Graecorum in totum Vetus Testamentum. Oxford: Clarendon, 1875.

Gelston, Anthony, ed. תרי עשר: The Twelve Minor Prophets. BHQ Fascicle 13. Stuttgart: Deutsche Bibelgesellschaft, 2010.

Gesenius, Wilhelm. Hebräisch-deutsches Handwörterbuch über die Schriften des Alten Testaments. Vol. 2. Leipzig: Vogel, 1812.

Gesenius, Wilhelm. Hebräisches Elementarbuch. 1oth ed. Halle: Rengersche VerlagsBuchhandlung, 1831 .

Kautzsch, Emil Friedrich, ed. Wilhelm Gesenius' hebräische Grammatik. 25th ed. Leipzig: F. C. W. Vogel, 1889.

Kittel, Rudolf. Biblia Hebraica. Vol. 2. Leipzig: J. C. Hinrichs, 1906.

Michaelis, Johann David. Supplementa ad lexica hebraica. Edited by Thomas Christian Tychsen. Vol. 6. Göttingen: Georg Rosenbusch, 1792.

Stec, David. The Dictionary of Classical Hebrew. Edited by David J. A. Clines. Vol. 6: פSheffield: Sheffield Phoenix Press, 2007.

Ullendorff, Edward. Ethiopia and the Bible: The Schweich Lectures of the British Academy, 1967. London: Oxford University Press, 1968.

Wilde, Arie de. "Vervreemding in Job 24:10, 11 (Mededeling)." Nederlands Theologisch Tijdschrift 28 (1974): 165 . 